Creative Commons User License: CC BY-NC-ND

Abstracted by: EBSCOhost, Electronic Journals Service (EJS),

Google Scholar, Journal Seek, Scientific Commons,

Food and Agricultural Organization (FAO), CABI and Scopus

http://eoi.citefactor.org/10.11226/v25i1
Journal of Agricultural Extension

Vol. 25 (1) January, 2021

ISSN(e): 24086851; ISSN(Print); 1119944X

http://journal.aesonnigeria.org

http://www.ajol.info/index.php/jae

Email: editorinchief@aesonnigeria.org

\title{
Perceived Effects of Professionalization of Extension Services by Public and Private Agents in South West Nigeria
}

https://dx.doi.org/10.4314/jae.v25i1.7

\section{Olorunfemi, Oluwasogo David}

Agricultural Extension and Rural Resource Management, School of Agricultural Sciences, University of Mpumalanga, Mbombela, South Africa, davidsoa2003@yahoo.com $+27839862245$

\section{Oladele, Oladimeji Idowu}

Sasakawa Africa Fund for Extension Education (SAFE), Ethiopia. oladele20002001@yahoo.com $+2348148768261$

\section{Olorunfemi, Temitope Oluwaseun}

Sightsavers Nigeria Country Office, Kaduna, Nigeria. oladeletemitope22@yahoo.com $+2348064490205$

Abstract

This study analysed the perceived effects of professionalization of extension services by extension agents in South West Nigeria. A structured questionnaire was used to elicit data from three hundred and one (301) public agents and fifty-five (55) private agents that were selected through a stratified random sampling procedure. The public and private agents had basic knowledge about the concept of professionalization and exhibited a favourable attitude towards professionalizing extension services. There were significant differences in the years of experience $(t=5.35, P \leq 0.01)$, farmers group covered $(t=-14.09, P \leq 0.01)$ and distance to clients travelled $(t=-$ 7.65, $P \leq 0.01)$ by the public and private agents. Extension agents in both organizations had a positive perception of the effects of professionalization of extension services in enhancing and improving delivery. Extension agents' knowledge $(t=5.303)$, attitude $(t=12.733)$, years of experience $(t=2.758)$, educational qualification ( $t=2.037)$ and rural-urban background $(t=2.061)$ were significant determinants of their perceived effects of professionalization on service delivery. Extension agencies should support continuous professional development of extension agents through trainings and acquisition of relevant higher degrees that will help to enhance their knowledge thus upgrading their professionalization-readiness status.

Keywords: Extension agents, extension service, perceived effects, professionalization.

\section{Introduction}

Globally, the phenomenon of extreme poverty is dominant among rural dwellers with majority of them depending on agriculture (FAO, 2016). Agriculture is the single largest employer and source of income in the world as it provides livelihoods for over 40 percent of the global population (United Nations, 2015). Agricultural extension plays a significant role in global food production and supply, and it remains a fundamental means of reaching farming households in the rural areas (Davis, 2015). 
Creative Commons User License: CC BY-NC-ND

Abstracted by: EBSCOhost, Electronic Journals Service (EJS),

Google Scholar, Journal Seek, Scientific Commons,

Food and Agricultural Organization (FAO), CABI and Scopus

http://eoi.citefactor.org/10.11226/v25i1
Journal of Agricultural Extension

Vol. 25 (1) January, 2021

ISSN(e): 24086851; ISSN(Print); 1119944X

http://journal.aesonnigeria.org

http://www.ajol.info/index.php/jae

Email: editorinchief@aesonnigeria.org

Agricultural development in many countries including Nigeria is hinged on extension services which help farmers to identify, analyse and link with research on their production problems. They also create awareness on opportunities for improvement of farm yields leading to increased income and better standard of living (Davis and Terblanche, 2016).

Globally, current discussions in the field of agricultural extension are tending towards professionalization of extension and advisory services. This is a fall out from the incessant complaints by farmers and other stakeholders about poor extension service delivery evident by inefficiency and poor timeliness of service, low knowledge level of extension agents, poor information and communication technology skills, unaccountability for the services rendered and poor links to research. All these have necessitated the need for countries to focus attention on professionalizing their extension and advisory services.

The concept of professionalization in agriculture has been popping-up as issues for priority discuss among academics, extension practitioners, policy makers and other stakeholders in the sector (Terblanche, 2015). Krishna (2018) defined professionalization as a social process by which any occupation transforms itself into a true profession of the highest integrity and competence while Terblanche (2017) emphasize professionalization as involving the adherence to ethical standards and codes that are enforced by the profession and acknowledged and accepted by the community. Professionalism goes beyond having extraordinary mastery over knowledge and skills of a subject matter. It has to do with having a knowledge base that is kept up-to-date, competency or ability to get the job done, self-regulation, showing respect and integrity in behaviour as well as ethical conduct (Agunga, Sleshi and Hassen, 2017). Therefore, in extension service, professionalism is evident when expertise in terms of knowledge and skills combines with integrity and ethics resulting in a competent, highly capable, committed, responsive and accountable extension practitioner.

Professionalization as operationalized in this study includes three major components of accreditation, registration and certification of extension service providers. Accreditation involves the process of ensuring that an individual has gone through a professional programme that meets the prescribed standard for a profession (Olorunfemi and Oladele, 2018). Registration ensures that an individual has passed some qualifying examinations and met the specified standards of professional training for a profession while Certification is the process whereby a professional society/body attests to the professional qualification of an individual and thus gives the right to practice of the occupation or profession for which minimum standards of education and experience have been met (Olorunfemi and Oladele, 2018). Closely related to these three components is the issue of continuous professional development over the years of practice by an individual. Professionalization of extension services will thus enhance the image of extension profession, promote credibility and accountability in the extension profession, regulate the professional conduct of extension personnel and ensure the competence of extension agents 
Creative Commons User License: CC BY-NC-ND

Abstracted by: EBSCOhost, Electronic Journals Service (EJS),

Google Scholar, Journal Seek, Scientific Commons,

Food and Agricultural Organization (FAO), CABI and Scopus

http://eoi.citefactor.org/10.11226/v25i1
Journal of Agricultural Extension

Vol. 25 (1) January, 2021

ISSN(e): 24086851; ISSN(Print); 1119944X

http://journal.aesonnigeria.org

http://www.ajol.info/index.php/jae

Email: editorinchief@aesonnigeria.org

through their accreditation and registration with a recognized and credible professional body (Terblanche, 2015).

Over the years, in Nigeria, there has been a growing concern for the provision of quality, efficient and sustainable agricultural extension services to majority of farmers who are responsible for the bulk of agricultural production (Oguniyi et al, 2020). Extension practitioners are said to be unresponsive to farmers' need, unaccountable for services rendered, not liable for unethical conduct, prone to incorrect and wrong message dissemination and general inefficient service delivery. This thus calls for a case to be made for the professionalization of extension in Nigeria. The Global Forum for Rural Advisory Services (GFRAS) through the several country fora has a mandate which is being implemented to revitalize agricultural extension by ensuring that countries have legislated extension policy and that there is professionalization of extension service providers (Davis, 2015). Terblanche (2015) reports that countries such as South Africa and Ghana have taken the lead in Africa in implementing this mandate and the Nigeria Forum for Agricultural Extension and Advisory Services (NIFAAS) is coordinating the activities to unlock extension sector for accountability and efficient service delivery.

In view of these therefore, as an organizational response to the pressure from an increasingly complex and rapidly changing environment, and in line with the current GFRAS global agenda, there is the need to determine the professionalizationreadiness of extension agents in South West Nigeria; by examining public and private extension agents' perception of the effects of professionalization of extension services vis-à-vis the advantages and disadvantages of this concept as being implemented. This will provide an in-depth insight to creating the solid foundation needed to properly refocus strategies that will be employed in restructuring extension and advisory service delivery in Nigeria.

Thus, the purpose of the study was to analyse the perceived effects of professionalization of extension services by public and private agents in South West Nigeria. The focus was to determine the perceived effects of professionalization on extension service delivery of all extension agents operating as both public and private service providers in South West Nigeria and not comparative analysis of this fairly burgeoning concept. Specifically, the study sought to describe the characteristics of the extension agents, determine the perceived effects of professionalization on extension service delivery and identify the determinants of the extension agents' perception of the effects of professionalization.

\section{Methodology}

The study was carried out in South Western Nigeria which lies between Latitude $6^{0}$ to the North and Latitude $4^{0}$ to the South. It is marked by Longitude $4^{0}$ to the West and $6^{0}$ to the East. The zone comprises six states (Oyo, Osun, Ondo, Ogun, Ekiti, and Lagos), The geographical location of South West Nigeria covers about 114, 271kilometre square, that is, approximately $12 \%$ of Nigeria's total land mass. The study population is all extension agents in the public and private extension organizations in 
Creative Commons User License: CC BY-NC-ND

Abstracted by: EBSCOhost, Electronic Journals Service (EJS),

Google Scholar, Journal Seek, Scientific Commons,

Food and Agricultural Organization (FAO), CABI and Scopus

http://eoi.citefactor.org/10.11226/v25i1
Journal of Agricultural Extension

Vol. 25 (1) January, 2021

ISSN(e): 24086851; ISSN(Print); 1119944X

http://journal.aesonnigeria.org

http://www.ajol.info/index.php/jae

Email: editorinchief@aesonnigeria.org

the zone. In this study, public extension agents are employees of the Agricultural Development Programme (ADP) and there were a total of 653 public extension agents across the six states ADP and 70 private extension agents in the zone.

A structured questionnaire was used to elicit data from three hundred and one (301) public agents and fifty-five (55) private agents. The public extension agents were selected through a two-staged sampling procedure. The first was a purposive selection of Ogun, Osun and Oyo States where extension personnel were prominent based on the information obtained from the various extension agencies in the states. The second stage was a random selection of 87, 129 and 85 extension agents in Ogun, Osun and Oyo States respectively. The proportionate sample size selected in each state was determined through the use of the Raosoft sample size calculator. This gave a total of three hundred and one (301) public extension personnel selected for the study.

The private extension agents were also selected through a two-staged sampling procedure. The first stage was a purposive selection of two prominent agro-based Non-Governmental Extension Organizations out of the four major ones in the zone. This selection was based on their employee base and current activities in the area. Those selected were FADU and JDPM-RUDEP having a total extension employee base of 23 and 35 respectively. The second stage was a random selection of 22 and 33 extension personnel from FADU and JDPM-RUDEP respectively. The proportionate sample size selected in each NGEO was also determined through the use of Roasoft sample size calculator. This gave a total of fifty-five (55) private extension agents.

The survey instrument was face-validated by experts in the field of agricultural extension and administration both in South Africa and Nigeria. A pre-test of the instrument was carried out in Kwara State using the split-half method of reliability. A high reliability coefficient 0.87 was obtained which showed proper consistency of the instrument. The questionnaire was made up of four sections each focused on a particular objective of the study. The first sought information on the characteristics of the extension agents. The second elicited data on the knowledge of the extension agents on professionalization and its components. The knowledge score of the extension agents was computed from a total of 36 items relating to the concept of professionalization and its components and graded as true (2) and false (1). The overall Knowledge Score of the respondents was determined from a range of 36 to 72 being the highest knowledge score possible. The statements used in generating the knowledge score for the respondents are: Professionalization is a process of setting up policies and structures to guide the extension profession, signifies commitment by extension agents to maintain currency of skills and knowledge in the profession, ensures only extension agents that have met the professional required standards are certified by recognized professional bodies, ensures appropriate regulation for extension service, is a mechanism for ensuring that extension agents abide by the code of ethics set for the practice of the extension profession, is a mechanism to protect, promote and ensure extension service sensitivity to the 
Creative Commons User License: CC BY-NC-ND

Abstracted by: EBSCOhost, Electronic Journals Service (EJS),

Google Scholar, Journal Seek, Scientific Commons,

Food and Agricultural Organization (FAO), CABI and Scopus
Journal of Agricultural Extension

Vol. 25 (1) January, 2021

ISSN(e): 24086851; ISSN(Print); 1119944X

http://journal.aesonnigeria.org

http://www.ajol.info/index.php/jae

Email: editorinchief@aesonnigeria.org

http://eoi.citefactor.org/10.11226/v25i1

needs of farmers, ensures periodic quality review of extension personnel and the services they render, promotes efficient and effective use of resources and access to certified information on infrastructures and facilities for service delivery, legalizes extension practice, points out areas of improvement in extension service delivery, involves consistent monitoring, evaluation and assessment of extension services, sets a foundation for continuous improvement in service delivery. The statements further include accreditation is an essential criteria for professionalization of extension service, a channel of injecting more integrity and competence into extension service delivery, a mechanism for quality improvement and assurance in extension service delivery, promotes accountability, promotes credibility, will improve standards of practice in the extension profession, strengthens community confidence in quality of service delivery, ensures a disciplined, systematic and reliable approach to extension training. The statements on registration include: Registration is an essential criteria for professionalization of extension service, a channel of injecting more integrity and competence into extension service delivery, a mechanism for quality improvement and assurance in extension service delivery, promotes accountability, promotes credibility, will improve standards of practice in the extension profession, strengthens community confidence in quality of service delivery, ensures a disciplined, systematic and reliable approach to extension training. Finally, statements on certification are: certification is an essential criteria for professionalization of extension service, a channel of injecting more integrity and competence into extension service delivery, a mechanism for quality improvement and assurance in extension service delivery, promotes accountability, promotes credibility, will improve standards of practice in the extension profession, strengthens community confidence in quality of service delivery, ensures a disciplined, systematic and reliable approach to extension training.

The third section sought data on the attitude of the extension agents towards professionalization. The attitude of the public and private extension agents was measured as a pooled score from 43 standardized attitudinal statements on professionalization and its components of accreditation, registration and certification and rated on a 5-point Likert-type scale of strongly agree (5), agree (4), undecided (3), disagree (2), strongly disagree (1). A total attitudinal score per respondents was generated with 43 being the least score and 215 being the maximum score possible. The list of statements used in generating the attitudinal score for the respondents covers professionalization: improves the image of the extension profession, protects the interest of the extension profession, enhances leadership and administrative capabilities; increases my productivity; improve the linkage system between extension and other stakeholders in the agricultural profession, increase agents' job satisfaction, increases the workload and demand of extension agents, improve the rights of farmers, brings about motivation and better work conditions, makes extension personnel to be more prone to chances of litigation from farmers encourage more team work, networking and collaboration in the sector and serves as base for further initiatives to improve service delivery. The statement also include accreditation will improve the quality of extension service delivery, ensures high level of integrity and ethical conduct in the extension profession, conditions and demands 
Creative Commons User License: CC BY-NC-ND

Abstracted by: EBSCOhost, Electronic Journals Service (EJS), Google Scholar, Journal Seek, Scientific Commons,

Food and Agricultural Organization (FAO), CABI and Scopus
Journal of Agricultural Extension

Vol. 25 (1) January, 2021

ISSN(e): 24086851; ISSN(Print); 1119944X

http://journal.aesonnigeria.org

http://www.ajol.info/index.php/jae

Email: editorinchief@aesonnigeria.org

of accreditation will be too much for extension agents, make extension work more stressful and cumbersome, the standard of entry and practice in the extension profession will be raised through accreditation, promote competent and need-driven extension service delivery, enhance the much needed transformation in the extension sector, continuous knowledge upgrade and development will be encouraged through accreditation, increase the confidence of extension agents, provide a proper foundation and sense of direction for the extension profession. Further statements are registration will improve the quality of extension service delivery, ensures high level of integrity and ethical conduct in the extension profession, conditions and demands of registration will be too much for extension agents, make extension work more stressful and cumbersome, the standard of entry and practice in the extension profession will be raised through registration, promote competent and need-driven extension service delivery, enhance the much needed transformation in the extension sector, continuous knowledge upgrade and development will be encouraged through registration, increase the confidence of extension agents, provide a proper foundation and sense of direction for the extension profession. Finally, statements on certification are: certification will improve the quality of extension service delivery, ensures high level of integrity and ethical conduct in the extension profession, conditions and demands of certification will be too much for extension agents, make extension work more stressful and cumbersome, the standard of entry and practice in the extension profession will be raised through certification, promote competent and need-driven extension service delivery, enhance the much needed transformation in the extension sector, continuous knowledge upgrade and development will be encouraged through certification, increase the confidence of extension agents, provide a proper foundation and sense of direction for the extension profession.

The fourth elicited data on the perceived effects of professionalization of extension services. Respondents were presented with a list of 26 effects of professionalization on extension services measured on a 4-point Likert scale of greatly improve (4), improve (3), slightly improve (2), not improve (1). The actual mean of 2.5 was then chosen as a cut-off point due to the rating scale used.

Data were analysed with IBM-SPSS Statistics 22.0, using percentages, means, tTest, principal component analysis and regression analysis. t-Test assessed whether the means of public and private groups were statistically different from each other with probability levels selected at $1 \%$ and $5 \%$ level of significance. Principal Component Analysis (PCA) which is a data reduction tool was used to extract the key components structure of the perceived effects of extension professionalization on delivery and a composite index of the extension agents' perceived effect was generated. The generated perception index was then used as a dependent variable and regressed with some explanatory variables in order to identify the determinants of the extension agents' perceived effects of professionalization on service delivery. The PCA model is thus stated as 


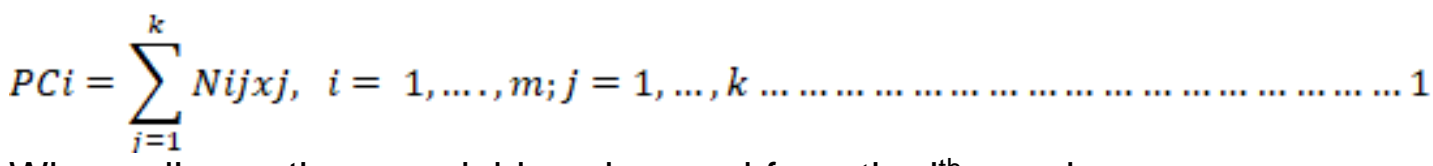

Where $x j^{\prime}$ are the $m$ variables observed from the $i^{\text {th }}$ member.

$\mathrm{PCi}=$ Perceived effect index

$\mathrm{N}=$ number of effect items used in the study

\section{Results and Discussion}

\section{Characteristics of Extension Agents}

The public agents were mainly Higher National Diploma (HND) holders while there were more degree holders among the private agents suggesting that the private extension agents had higher educational qualification and were more focused on continuous knowledge upgrade than their public counterparts. There is also a statistical significant difference $(t=5.35, P \leq 0.01)$ in the average years of experience of the two groups suggesting that public extension agents are generally more experienced in extension work than their private counterparts and they will have more exposure and practical knowledge of field work. The public and private agents were predominantly living in their job location and mostly of rural background. This is similar to what is obtainable in South Africa as extension officers predominantly reside in their job location (Oladele, 2015). This attribute is expected to facilitate the effectiveness of extension service delivery in the area if the agents discharge their duties professionally.

The results in Table 1 also revealed that most of the extension agents in both organizations were not involved in acquiring any form of higher degree qualification as at the time of the study, this implies that majority of the extension agents were not given to continuous professional development especially as it relates to higher educational qualifications. This agrees with the findings of Demenongu, Okwu and Okwoche (2015) who stated that only few extension agents in South West Nigeria were studying for higher degree. Furthermore, Public agents mainly used motorcycle as mobility to reach their clients whereas on the other hand private agents mostly used vehicles in getting to their clients' location. The average number of farmer groups covered by the public and private agents was 23.86 and 49.27 groups respectively. The result of the $t$-test carried out shows a significant difference $(t=-$ 14.09. $p \leq 0.01)$ in the number of farmer groups covered by the two groups. This implies that the private agents covered more number of farmer groups than the public agents due to the fewer number of agents in the private extension organizations. However, on the average, the farmer group covered per extension agents is still very high and this agrees with Olorunfemi, Olorunfemi and Oladele (2020) who reported a very high extension to farmer ration in South West Nigeria. The average distance to client travelled by the public and private agents was $21.27 \mathrm{~km}$ and $11.09 \mathrm{~km}$ respectively. The result of the t-test however confirms a significant difference in distance travelled by the two groups of agents $(t=-7.65, p \leq$ 0.01 ). This implies that the public agents travelled longer distances before reaching their clients than the public agents. The overall shortage of extension personnel in 
Creative Commons User License: CC BY-NC-ND

Abstracted by: EBSCOhost, Electronic Journals Service (EJS),

Google Scholar, Journal Seek, Scientific Commons,

Food and Agricultural Organization (FAO), CABI and Scopus

http://eoi.citefactor.org/10.11226/v25i1
Journal of Agricultural Extension

Vol. 25 (1) January, 2021

ISSN(e): 24086851; ISSN(Print); 1119944X

http://journal.aesonnigeria.org

http://www.ajol.info/index.php/jae

Email: editorinchief@aesonnigeria.org

the area is a contributory factor to the high average distance to client travelled by the agents which in-turn makes extension work less effective in the area.

Table 1: Characteristics of public and private extension agents

\begin{tabular}{|c|c|c|c|}
\hline Variables & Public agents $(n=301)$ & Private agents $(n=55)$ & t-stat \\
\hline Education qualification & Mainly HND holders (50.0\%) & Mainly degree holders (52.8\%) & \\
\hline Years of experience & $12.54(7.30)$ & $8.36(4.89)$ & $5.35^{\star * *}$ \\
\hline Living in job location & Mainly living in job area (64.8\%) & Mainly living in job area (96.4\%) & \\
\hline Farmers group covered & 23.86(9.29) & $49.27(12.77)$ & $-14.09^{* * *}$ \\
\hline Means of mobility & Mainly by motorcycle $(76.7 \%)$ & Mainly by vehicle $(61.8 \%)$ & \\
\hline $\begin{array}{l}\text { Involvement in higher } \\
\text { degree }\end{array}$ & Mainly not involved (82.1\%) & Mainly not involved $(80.0 \%)$ & \\
\hline Distance to clients & $11.09(4.77)$ & $21.27(9.66)$ & $-7.65^{\star * *}$ \\
\hline Background & Mainly rural $(58.1 \%)$ & Mainly rural $(52.7 \%)$ & \\
\hline
\end{tabular}

\section{Knowledge of the Extension Agents on Professionalization of Agricultural Extension Services}

Table 2 shows that the majority of the public (86.0\%) and private (89.1\%) extension agents had high knowledge on the concept of professionalization and its components. The average knowledge score of the public and private agents was 65.42 and 66.04 respectively implying that the agents in both extension agencies had the basic knowledge about the concept of professionalization. This is in consonance with the findings of Olorunfemi and Oladele (2018) that extension agents in South West Nigeria were knowledgeable about the basic intricacies of the concept and process of professionalization. This bodes well for the implementation of professionalization of extension services in the study area.

Table 2: Knowledge score on professionalization

\begin{tabular}{|c|c|c|c|c|c|}
\hline $\begin{array}{l}\text { Knowledge } \\
\text { Score }\end{array}$ & $\begin{array}{l}\text { Pub } \\
(n=3\end{array}$ & ision Agents & Prive & $\begin{array}{l}\text { ension Agents } \\
=55)\end{array}$ & t-stat \\
\hline & $\%$ & Mean(SD) & $\%$ & Mean(SD) & \\
\hline $\begin{array}{l}36-60 \text { Low } \\
\text { Knowledge } \\
\text { (Below } 70 \% \text { ) }\end{array}$ & 14.0 & $65.42(4.66)$ & 10.9 & $66.04(4.46)$ & -0.934 \\
\hline $\begin{array}{l}61-72 \text { High } \\
\text { Knowledge } \\
\text { ( } 70 \% \text { and } \\
\text { above) }\end{array}$ & 86.0 & & 89.1 & & \\
\hline
\end{tabular}

\section{Attitude of the Extension Agents toward Professionalization of Agricultural Extension Services}

Table 3 shows that the majority of the public (98.7\%) and private (98.2\%) exhibited a favourable attitude towards professionalizing extension services. The mean attitudinal score for the public and private agents was 169.50 and 167.49 
Creative Commons User License: CC BY-NC-ND

Abstracted by: EBSCOhost, Electronic Journals Service (EJS),

Google Scholar, Journal Seek, Scientific Commons,

Food and Agricultural Organization (FAO), CABI and Scopus
Journal of Agricultural Extension

Vol. 25 (1) January, 2021

ISSN(e): 24086851; ISSN(Print); 1119944X

http://journal.aesonnigeria.org

http://www.ajol.info/index.php/jae

Email: editorinchief@aesonnigeria.org

respectively. The favourable disposition expressed by the extension agents implies that they have an understanding of what the sector has to benefit from professionalization in terms of enhancing and improving extension service delivery. This is in line with Olorunfemi (2018) who reported that majority of extension agents in South West Nigeria agree with professionalization of extension services. This provides a good platform to leverage upon in driving professionalization and its processes in the study area.

Table 3: Attitudinal score on professionalization

\begin{tabular}{llllll}
\hline $\begin{array}{l}\text { Attitude } \\
\text { Score }\end{array}$ & $\begin{array}{c}\text { Public Extension Agents } \\
(\mathbf{n = 3 0 1 )}\end{array}$ & $\begin{array}{c}\text { Private Extension Agents } \\
(\mathbf{n = 5 5 )}\end{array}$ & t-stat \\
\hline & $\%$ & Mean(SD) & $\%$ & Mean(SD) & \\
\hline $\begin{array}{l}\text { 43-128 } \\
\text { Unfavourable }\end{array}$ & 1.3 & $169.50(20.86)$ & 1.8 & $167.49(20.64)$ & 0.66 \\
$\begin{array}{l}\text { Attitude } \\
\text { (Below 50\%) }\end{array}$ & & & & & \\
$\begin{array}{l}129-215 \\
\text { Favourable }\end{array}$ & 98.7 & & & & \\
$\begin{array}{l}\text { Attitude } \\
\text { (50\% and }\end{array}$ & & & 98.2 & & \\
above) & & & & & \\
\hline
\end{tabular}

\section{Perceived Effects of Professionalization of Extension Services}

The results from Table 4 show that the extension agents in the public and private extension organisations had a positive perception of the effects of professionalization of extension services in enhancing and improving delivery. The most prominent statements on perceived effects of professionalization highlighted by the public extension agents were, "improvement of quality and credibility of extension service delivery" $\left(\bar{X}_{\text {pub }}=3.42, S D=0.56\right)$, "provision of a mechanism and channel for feedback in extension services" $\left(\bar{X}_{\text {pub }}=3.34, S D=0.64\right)$, "enhancing the professional image of the extension profession" $\left(\bar{X}_{p u b}=3.33, S D=0.64\right)$, "enhancing integrity and ethics in the extension profession" $\left(\bar{X}_{\text {pub }}=3.31, S D=0.68\right)$ and "regulation of the extension profession" $\left(\bar{X}_{p u b}=3.29, S D=0.81\right)$.

The private extension agents also positively perceived that professionalization, when fully implemented, is going to improve and enhance service delivery in the area by, "providing a mechanism and channel for feedback in extension services" $\left(\bar{X}_{p r i}=3.36, S D=0.80\right)$, "assist in identification and tracking of extension personnel identity" $\quad\left(\bar{X}_{\text {pri }}=3.35, S D=0.75\right)$, "enhance accountability in the extension profession" ( $\left.\bar{X}_{p r i}=3.30, S D=0.77\right)$, "provision of risk management mechanism and demonstration of due diligence" $\left(\bar{X}_{\text {pri }}=3.29, S D=0.83\right)$, "enhance networking of like-minded professionals and peer group acceptance" $\left(\bar{X}_{\text {pri }}=3.29, S D=0.81\right)$ and "reduction of rifts between extension agents and farmers" $\left(\bar{X}_{\text {pri }}=3.29, S D=0.71\right)$. 
Creative Commons User License: CC BY-NC-ND

Abstracted by: EBSCOhost, Electronic Journals Service (EJS), Google Scholar, Journal Seek, Scientific Commons,

Food and Agricultural Organization (FAO), CABI and Scopus

http://eoi.citefactor.org/10.11226/v25i1
Journal of Agricultural Extension

Vol. 25 (1) January, 2021

ISSN(e): 24086851; ISSN(Print); 1119944X

http://journal.aesonnigeria.org

http://www.ajol.info/index.php/jae

Email: editorinchief@aesonnigeria.org

There were significant differences in the perception of the public and private extension agents on the effect of professionalization on service delivery on two statements which were, "enhance job motivation" $\left(\bar{X}_{p u b}=2.85\right.$, $\left.\bar{X}_{p r i}=3.18 ; t=2.18, p \leq 0.05\right)$ and "improve job satisfaction" $\left(\bar{X}_{\text {pub }}=2.98\right.$, $\bar{X}_{\text {pri }}=3.25 ; t=1.95, p \leq 0.05$ ). This implies that the public and private agents held different opinions on the effects of extension professionalization regarding these statements. The lower positive perception exhibited by the public agents might be as a result of the fact that the public extension agents are not entirely convinced that professionalization is a channel that can increase their staff welfare packages. This is in congruence with the assertion of Okwoche, Eziehe and Agabi (2015) that public extension agents job satisfaction increases with increase in salary and welfare packages. Also the comparative lower educational qualification of the public extension agents as against their private counterparts might have influenced their low perception of professionalization as a channel of enhancing job motivation because, as Adesiji et al. (2015) stated, increase in educational level is directly related to public extension agents' job motivation in Kwara State, Nigeria. 
Creative Commons User License: CC BY-NC-ND

Abstracted by: EBSCOhost, Electronic Journals Service (EJS), Google Scholar, Journal Seek, Scientific Commons,

Food and Agricultural Organization (FAO), CABI and Scopus

http://eoi.citefactor.org/10.11226/v25i1
Journal of Agricultural Extension

Vol. 25 (1) January, 2021

ISSN(e): 24086851; ISSN(Print); 1119944X

http://journal.aesonnigeria.org

http://www.ajol.info/index.php/jae

Email: editorinchief@aesonnigeria.org

Table 4: Perceived effects of professionalization of extension on improving and enhancing service delivery

\begin{tabular}{|c|c|c|c|}
\hline Effects & $\begin{array}{l}\text { Public } \\
\text { Agents }\end{array}$ & $\begin{array}{l}\text { Private } \\
\text { Agents }\end{array}$ & t-stat \\
\hline & Mean(SD) & Mean(SD) & \\
\hline \multicolumn{4}{|l|}{ Accreditation } \\
\hline Accountability in the extension profession & $3.2(0.7)$ & $3.3(0.8)$ & -0.36 \\
\hline Enhancement of clients(farmers) confidence and satisfaction & $3.1(0.8)$ & $3.3(0.8)$ & -1.42 \\
\hline $\begin{array}{l}\text { Maintenance of currency of knowledge and skills at all levels } \\
\text { by extension agents }\end{array}$ & $3.1(0.8)$ & $3.2(0.9)$ & -0.43 \\
\hline Regulation of the extension profession & 3.3(0.8) & $3.2(0.7)$ & -0.19 \\
\hline Extension service working conditions & $3.1(0.7)$ & $3.1(0.8)$ & 0.28 \\
\hline Sensitivity to accurately solving farmers need & $3.1(0.8)$ & $3.1(0.9)$ & -0.18 \\
\hline Integrity and ethics in the extension profession & $3.3(0.7)$ & 3.3(0.9) & 0.42 \\
\hline $\begin{array}{l}\text { Networking of like-minded professionals and peer group } \\
\text { acceptance }\end{array}$ & $3.2(0.8)$ & $3.3(0.8)$ & -0.53 \\
\hline $\begin{array}{l}\text { Transparency in extension services and reduction in man } \\
\text { know man issues }\end{array}$ & $3.1(0.8)$ & $3.2(0.8)$ & -1.37 \\
\hline \multicolumn{4}{|l|}{ Registration } \\
\hline Specialization of extension agents in service delivery & $3.1(0.8)$ & $3.2(0.9)$ & -1.71 \\
\hline Research culture and skills among extension agents & $3.1(0.8)$ & $3.0(0.9)$ & 0.81 \\
\hline Elimination of lackadaisical attitude among extension agents & $3.1(0.7)$ & $3.2(0.9)$ & -0.26 \\
\hline $\begin{array}{l}\text { Provision of risk management mechanism and demonstration } \\
\text { of due diligence }\end{array}$ & $3.2(0.8)$ & $3.3(0.7)$ & -0.81 \\
\hline Reduction of rifts between extension agents and farmers & $3.1(0.8)$ & $3.3(0.7)$ & -1.63 \\
\hline Mechanism and channels for feedback in extension services & $3.3(0.6)$ & $3.4(0.8)$ & -0.22 \\
\hline Identification and tracking of extension personnel identity & $3.2(0.8)$ & $3.4(0.8)$ & -1.58 \\
\hline $\begin{array}{l}\text { Extension personnel paying more attention to details } \\
\text { Certification }\end{array}$ & & -0.06 \\
\hline Professional image of the extension profession & 3.3(0.6) & $3.1(0.9)$ & 1.58 \\
\hline Quality and credibility of extension service & $3.4(0.6)$ & $3.3(0.9)$ & 1.23 \\
\hline Confidence of extension agents & $3.2(0.8)$ & $3.3(0.8)$ & -0.84 \\
\hline $\begin{array}{l}\text { Enhancement of the decision making capabilities of extension } \\
\text { agents }\end{array}$ & $3.1(0.8)$ & $3.2(0.8)$ & -1.08 \\
\hline Job motivation & $2.9(0.8)$ & $3.2(1.0)$ & $2.18^{* *}$ \\
\hline Strength of extension organization and profession & $3.1(0.7)$ & $3.0(0.8)$ & 1.04 \\
\hline Job satisfaction & $2.9(0.7$ & $3.3(0.9)$ & $1.95^{\star *}$ \\
\hline Promotion of better and faster agricultural solution & $3.1(0.8)$ & $3.3(0.8)$ & -0.93 \\
\hline Improvement in quality of information in the sector & $3.1(0.8)$ & $3.1(0.9)$ & -0.09 \\
\hline
\end{tabular}

${ }^{\star *} P \leq 0.01$

\section{Determinants of Perceived Effects of Extension Professionalization on Service Delivery}

Table 5 reveals that there was a strong correlation between the independent variables and the perceived effect of extension professionalization on service delivery $\left(R^{2}=0.89\right)$. The model predicted about 79 per cent of the perceived effects of the extension agents and the F-value was statistically significant $(p \leq 0.01)$ showing that the model has a good fit. It was noted that the knowledge level $(t=5.303)$, attitude $(t=12.733)$ and educational qualification $(t=2.037)$ of the extension agents were significant at 1 per cent level of significance while their years of experience $(t=$ 2.758) and background ( $t=2.061)$ were significant at 5 per cent level of significance 
Creative Commons User License: CC BY-NC-ND

Abstracted by: EBSCOhost, Electronic Journals Service (EJS),

Google Scholar, Journal Seek, Scientific Commons,

Food and Agricultural Organization (FAO), CABI and Scopus

http://eoi.citefactor.org/10.11226/v25i1
Journal of Agricultural Extension

Vol. 25 (1) January, 2021

ISSN(e): 24086851; ISSN(Print); 1119944X

http://journal.aesonnigeria.org

http://www.ajol.info/index.php/iae

Email: editorinchief@aesonnigeria.org

implying that these five variables significantly determine the perceived effects of extension professionalization by extension agents in the study area hence the research hypothesis $\left(\mathrm{H}_{2}\right)$ was rejected. The coefficients of all the significant variables were positive implying that the explanatory variables all had a positive relationship on the extension agents' perceived effects of professionalization on service delivery.

The coefficient of the knowledge level (0.71) of the extension agents had a significant $(p \leq 0.01)$ and positive influence on the extension agents' perceived effects of professionalization of extension services on delivery. This indicates that a unit increase in the knowledge level of the extension agents will increase their perceived effects of extension professionalization on service delivery by 0.71 . This implies that an increase in the knowledge level of the extension agents on the concept of professionalization will lead to an increase in the perception of the agents on the effects that professionalization of extension will have on service delivery.

The parameters of the extension agents' attitude (0.39) had a positive and significant $(p \leq 0.01$ ) influence on their perceived effects of professionalization of extension services on delivery. This indicates that the exhibition of a positive attitude by the extension agents will also likely result in them having a positive perception of the effects of extension professionalization on service delivery. This is in agreement with the findings of Kazeem et al. (2017) that attitude exerted a positive influence on perceived effect or usefulness of an innovation.

Furthermore, in the model, the educational qualification (1.72) of the extension agents had a significant $(p \leq 0.05)$ and positive influence on their perceived effects of extension professionalization on service delivery. This indicates that there will be an improvement in the agents' perception of the effects of extension professionalization on service delivery as their educational qualification increases. This is supported by Oladele (2015) who reported that extension officers' level of education positively and significantly impacted on their perceived effects of information access in South Africa.

The parameter of years of experience (4.20) of the extension agents had a positive and significant $(p \leq 0.01)$ relationship on their perceived effects of professionalization of extension services on delivery. This indicates that extension agents that are well experienced in extension services had a higher likelihood of positively perceiving the effects of extension professionalization on service delivery in the study area. This is attributed to the fact that more years of experience is expected to have allowed them to know the pros and cons of the sector thus making them more matured and disposed to taking decisions that will positively enhance their growth and career productivity.

Finally, the estimated coefficient of the background (1.54) of the extension agents positively and significantly $(p \leq 0.05)$ influenced their perceived effects of professionalization of extension services on delivery. This may result from the fact 
Creative Commons User License: CC BY-NC-ND

Abstracted by: EBSCOhost, Electronic Journals Service (EJS),

Google Scholar, Journal Seek, Scientific Commons,

Food and Agricultural Organization (FAO), CABI and Scopus
Journal of Agricultural Extension

Vol. 25 (1) January, 2021

ISSN(e): 24086851; ISSN(Print); 1119944X

http://journal.aesonnigeria.org

http://www.ajol.info/index.php/jae

Email: editorinchief@aesonnigeria.org

that majority of the agents have their backgrounds from rural areas which is the hub of agricultural activities. This attribute is expected to make them familiar with the terrain and the plight faced by rural farmers thus engendering in them the willingness to adopt strategies that will place them in a position to serve their clients better and more effectively.

Table 5: Determinants of perceived effects of extension professionalization on service delivery

\begin{tabular}{lll}
\hline Variables & $\mathbf{B}(\mathbf{S E})$ & $\mathbf{T}$ \\
\hline (Constant) & $-43.241(9.804)$ & $-4.411^{\star \star *}$ \\
Knowledge & $0.711(0.134)$ & $5.303^{\star * \star}$ \\
Attitude & $0.394(0.031)$ & $12.733^{\star * \star}$ \\
Years of Experience & $4.204(1.524)$ & $2.758^{\star \star \star}$ \\
No. of Children & $0.121(0.629)$ & 0.193 \\
Educational Qual. & $1.721(0.845)$ & $2.037^{\star *}$ \\
Involvement in Higher degree & $0.011(0.168)$ & 0.064 \\
Living in Job location & $0.997(0.864)$ & 1.154 \\
No. of Farmer groups & $-0.031(0.036)$ & -0.852 \\
Means of Mobility & $0.643(0.836)$ & 0.769 \\
Distance Covered & $0.047(0.068)$ & 0.693 \\
Rural-Urban Background & $1.539(0.747)$ & $2.061^{\star \star}$ \\
\hline
\end{tabular}

$\mathrm{F}=81.217 ; \mathrm{P}=0.000 ; \mathrm{R}=0.896 ; \mathrm{R}$ sq. $=0.803 ;$ Adj. $\mathrm{R}$ sq. $=0.793$

${ }^{* * *} P \leq 0.01$ and ${ }^{* *} P \leq 0.05$

\section{Conclusion and Recommendation}

Professionalization-readiness of extension agents which is evident by their perception of the effects of the concept is influenced by their educational qualification and knowledge. Thus, there is the need for extension agencies to support continuous professional development of extension agents through training and acquisition of relevant higher degrees and facilitation of seminar that will enhance their knowledge in order to upgrade their professionalization readiness status.

\section{References}

Adesiji, G. B., Komolafe, S. E., Ifabiyi, J. O., Ajibola, B. O., and Animashaun, J. O. (2015). The perception of agricultural extension agents on job motivation in Kwara State Nigeria. Agrosearch, 15(1): 117-125.

Agunga, R., Sleshi, R., and Hassen, R. (2017). Towards a professionalism of agricultural extension: Key to promoting extension effectiveness in Africa. Sustainable Agriculture Research, 6(526-2017-2673).

Davis, K. E. (2015). The new extensionist: Core competencies for individuals. GFRAS Brief \#3. Lindau, Switzerland: Global Forum for Rural Advisory Services (GFRAS).

Davis, K. E., and Terblanché, S. E. (2016). Challenges facing the agricultural extension landscape in South Africa, Quo Vadis?. South African Journal of Agricultural Extension, 44(2): 231-247. 
Creative Commons User License: CC BY-NC-ND

Abstracted by: EBSCOhost, Electronic Journals Service (EJS), Google Scholar, Journal Seek, Scientific Commons,

Food and Agricultural Organization (FAO), CABI and Scopus
Journal of Agricultural Extension

Vol. 25 (1) January, 2021

ISSN(e): 24086851; ISSN(Print); 1119944X

http://journal.aesonnigeria.org

http://www.ajol.info/index.php/jae

Email: editorinchief@aesonnigeria.org

Demenongu, T. S., Okwu, O. J., and Okwoche, V. A. (2015). Assessment of Communication Competence of agricultural extension workers in Benue State, Nigeria. Journal of Agricultural \& Food Information, 16(2): 163-173.

Food and Agriculture Organization (FAO), 2016. Food and Agriculture Organization in the 2017 humanitarian appeals saving livelihoods saves lives. Available at www.fao.org/publications

Kazeem, A. A., Dare, A., Olalekan, O., Abiodun, S. E., and Komolafe, T. L. (2017). Attitudes of farmers to extension trainings in Nigeria: Implications for adoption of improved agricultural technologies in Ogun state southwest region. Journal of Agricultural Sciences, Belgrade, 62(4): 423-443.

Krishna, D. K. (2018). Strategies for Professionalization of Extension for 21st Century. Available at: https://www.slideshare.net/krishnadk/strategies-forprofessionalization-of-extension-for-21st-century

Oguniyi, A., Babu, S. C., Balana, B. and Andam, K. (2020). National Extension Policy and State-Level Implementation: The case of Cross River State, Nigeria. IFPRI Discussion Paper 01951. Available at: https://ebrary.ifpri.org

Okwoche, V. A. O., Eziehe, J. C., and Agabi, V., (2015). Determinants of job satisfaction among Extension Agents in Benue State Agricultural and Rural Development Authority (Bnarda), Benue State, Nigeria. European Journal of Physical and Agricultural Sciences, 3(2): 38-48.

Oladele, O. I. (2015). Effect of Information Communication Technology (ICT) on agricultural information access among extension officers in North West Province South Africa. South African Journal of Agricultural Extension, 43(2): 30-41.

Olorunfemi, T. O., Olorunfemi, O. D., and Oladele, O. I. (2020). Determinants of the involvement of extension agents in disseminating climate smart agricultural initiatives: Implication for scaling up. Journal of the Saudi Society of Agricultural Sciences, 19(4): 285-292.

Olorunfemi, O. D. (2018). Perceived effects of Professionalization of Extension Services on Delivery by Public and Private Agents in South Western Nigeria. An unpublished doctoral thesis submitted to the Department of Agricultural Economics and Extension, North West University, South Africa. 162pp.

Olorunfemi, O. D., and Oladele, O. I. (2018). Knowledge of extension agents regarding professionalization of extension services: Evidence from South West Nigeria. Journal of International Agricultural and Extension Education, 25(3): 33-50.

Terblanche, S. E. (2017). Advancing Agricultural Knowledge: Improving the Professionalism of Rural Advisory Services. GFRAS: Lausanne, Switzerland. Available at: www.gfras.org

Terblanche, F. (2015). Extension Science as a field of Practice. Towards Professionalization of Extensionists. The South African Example. Paper presented at the $6^{\text {th }}$ GFRAS Annual Meeting and Side Events, 14 -18 September 2015, Issyk Kul, Kyrgyzstan.

United Nations (2015). Sustainable Development Goals Fact Sheet. Available at: www.un.org/sustainabledevelopment/wp.../Factsheet Summit.pdf . 